\title{
Gambaran Biaya Langsung Medis Penyakit Pneumonia Dengan Terapi Ceftriaxone di Rawat Inap Rumah Sakit Umum Daerah X di NTB Tahun 2018.
}

\author{
Cyntiya Rahmawati ${ }^{a, 1^{\star}}$, Baiq Leny Nopitasari a,2, Nining Pratiwi Safitri a,3 \\ a,1,2 Dosen Program Studi Diploma Tiga Farmasi, Universitas Muhammadiyah Mataram, Mataram, Indonesia \\ a,3 Mahasiswa Program Studi Diploma Tiga Farmasi, Universitas Muhammadiyah Mataram, Mataram, Indonesia \\ ${ }^{1}$ cyntiya.apt@gmail.com *; ${ }^{2}$ baiqleny.nopitasari@gmail.com ; ${ }^{3}$ pratiwinining40@gmail.com \\ *korespondensi penulis
}

\begin{tabular}{ll}
\hline INFO ARTIKEL & ABSTRAK \\
\hline Diterima : & Pneumonia merupakan penyakit infeksi dengan jumlah kasus terbanyak di \\
23-I2-20I9 & Rumah Sakit Umum Daerah (RSUD) X di NTB tahun 20I8. Risiko kematian \\
Disetujui : & akibat pneumonia terutama di negara berkembang seperti di Indonesia serta \\
30-I2-20I9 & risiko tingginya biaya pelayanan kesehatan. Sehingga diperlukan pengelolaan \\
& biaya secara efektif dan efisien. Pilihan terapi untuk pneumonia yang digunakan \\
& di RSUD X di NTB salah satunya seftriakson. Penelitian ini bertujuan untuk \\
\hline Kata kunci : & menghitung rata-rata biaya langsung medis pada pasien pneumonia dengan \\
Gambaran biaya; & terapi seftriakson di rawat inap RSUD X di NTB tahun 20I8 dengan perspektif \\
Biaya langsung medis; & BPJS Kesehatan. Jenis penelitian ini adalah kuantitaif deskriptif dengan \\
Pneumonia; & menggunakan data sekunder. Komponen biaya langsung medis yang dihitung \\
Seftriakson; & adalah biaya obat, perawatan, dokter, IGD, akomodasi, dan laboratorium. \\
Rumah sakit. & Jumlah sampel diperoleh 30 pasien. Hasil penelitian pada pasien pneumonia \\
& yang menggunakan seftriakson menunjukkan: (I) Total biaya langsung medis \\
& sebesar Rp.9I.048.949,- dengan biaya minimal sebesar Rp.I.072.849,- dan \\
biaya maksimal sebesar Rp.8.582.643,- (2) Rata-rata biaya langsung medis & sebesar Rp.3.034.965,- per pasien, (3) Rata-rata biaya langsung medis kelas 2 \\
& sebesar Rp.3.2I2.737,- sedangkan kelas 3 sebsesar Rp.2.802.494,-.
\end{tabular}

Keywords :

Cost descriptive;

Direct medical cost;

Pneumonia;

Ceftriaxone;

Hospital.

\section{ABSTRACT}

Pneumonia is an infectious disease with the highest number of cases at the Regional General Hospital (RSUD) X in NTB in 20I8. The risk of death from pneumonia especially in developing countries like in Indonesia and the risk of high health care costs. So the effective and efficient cost management is needed. The therapeutic options for pneumonia used at RSUD X in NTB are ceftriaxone. This study aims to calculate the average direct medical costs in pneumonia patients with ceftriaxone therapy in RSUD X Hospital in NTB in 2018 with the perspective of BPJS Kesehatan. This type of research is descriptive quantitative using secondary data. The components of direct medical costs calculated are the costs of medicines, treatments, doctors, emergency room, accommodation, and laboratory. The number of samples obtained by 30 patients. The results of the study on pneumonia patients using ceftriaxone showed: (I) Total direct medical costs of Rp.9I.048.949,- with a minimum cost of Rp.I.072.849,- and a maximum cost of Rp.8.582.643,- (2) The average direct medical costs are Rp.3.034.965,- per patient, (3) The average direct medical costs for class 2 is Rp.3.2I2.737,- while for class 3 is Rp.2.802.494,-

\section{PENDAHULUAN}

Pneumonia merupakan radang paru yang disebabkan oleh mikroorganisme (bakteri, virus, jamur dan parasit). Proses peradangan akan menyebabkan jaringan paru yang berupa alveoli (kantong udara) dapat dipenuhi cairan ataupun nanah. Akibatnya kemampuan paru sebagai tempat pertukaran gas terutama oksigen (O2) akan terganggu. Bila pneumonia tidak ditangani dengan baik, proses peradangan akan terus berlanjut dan menimbulkan berbagai komplikasi seperti, selaput paru terisi cairan atau nanah (Efusi pleura atau emplema), jaringan paru bernanah (abses paru), jaringan paru kempis (pneumothoraks). Bahkan bila 
terus berlanjut dapat terjadi penyebaran infeksi melalui darah (sepsis) ke seluruh tubuh sehingga dapat menyebabkan kematian (Dahlan, 200I). Penyakit saluran napas menjadi penyebab angka kematian dan kecacatan yang tinggi di seluruh dunia. Sekitar $80 \%$ dari seluruh kasus baru praktek umum berhubungan dengan infeksi saluran napas yang terjadi di masyarakat (pneumonia komunitas) atau di dalam rumah sakit (pneumonia nosokomial).

Seftriakson adalah antibiotik spektrum luas generasi ketiga sefalosporin untuk pemberian intravena atau intramuscular. Seftriakson adalah salah satu antibiotik yang paling umum digunakan karena potensi antibakteri yang tinggi, spektrum yang luas dari aktivitas dan potensi yang rendah untuk toksisitas. Alasan yang paling mungkin untuk digunakan secara luas adalah efektivitas dalam organisme yang rentan pada infeksi saluran kemih yang rumit dan tidak rumit, infeksi saluran pernapasan, kulit, jaringan lunak, infeksi tulang dan sendi, bakteremia/septikemia, pneumonia, meningitis, infeksi di pasien imunosupresi, akut bakteri otitis media, infeksi genital, disebar luaskan.

Penanganan pneumonia yang tidak tepat dan tidak efektif dapat menimbulkan infeksi berulang yang berlanjut sehingga menyebabkan peningkatan biaya perawatan. Total biaya langsung dan tidak langsung untuk pneumonia di German, diperkirakan sampai \$I,64 milyar, yang terdiri atas \$983 juta biaya langsung dan $\$ 656$ juta biaya tidak langsung (Bauer et $\mathrm{al}, 2005)$. Menurut hasil penelitian Purwaningrum (2007) di Rumah Sakit PKU Muhammadiyah Yogyakarta, pada pasien pneumonia tanpa penyakit penyerta, biaya total selama rawat inap antara Rp.I.IOI.968,- sampai Rp.31.695.568,--. Sedangkan pada pasien pneumonia dengan penyakit penyerta, biaya total selama rawat inap antara Rp.2.I 19.287,sampai Rp.33.409.669,-. Melihat keadaan tersebut, maka upaya yang dilakukan untuk menanggulangi biaya terapi pneumonia adalah mengalokasikan dan mengelola dana secara lebih efisien dan efektif.

Berdasarkan studi pendahuluan yang dilakukan oleh peneliti, penyakit pneumonia di Rumah Sakit Umum Daerah (RSUD) X di NTB memasuki daftar I0 penyakit terbanyak di tahun 2018. Data penggunaan antibiotik yang paling sering di RSUD X di NTB untuk pasien pneumonia yaitu salah satunya obat seftriakson.

Berdasarkan uraian di atas, mendorong peneliti untuk melakukan penelitian yang bertujuan untuk mengetahui gambaran rata-rata biaya langsung medis penggunaan antibiotik seftriakson pada pasien pneumonia di Instalasi Rawat Inap RSUD X di NTB tahun 2018 dengan perspektif BPJS Kesehatan.

\section{METODE PENELITIAN}

Penelitian yang dilakukan menggunakan metode observasional deskriptif dengan mengambil data secara retrospektif pada periode Januari-Juli 2018. Data diambil dari data rekam medik, SIMRS, dan bagian keuangan yang berupa tarif pelayanan rumah sakit untuk mengetahui besarnya biaya terapi pengobatan seftriakson pada pasien rawat inap pneumonia. Penelitian dilakukan di RSUD X di NTB. Waktu penelitian dilakukan pada Agustus 2018.

Populasi penelitian adalah pasien yang di diagnosis pneumonia CAP (Community Acquired Pneumonia) yang menjalani rawat inap periode Januari-Juli tahun 2018 sebanyak I58 orang. Teknik sampling menggunakan metode purposive sampling. Sampel penelitian adalah adalah pasien pneumonia CAP yang mendapatkan terapi obat antibiotik seftriakson di rawat inap RSUD X di NTB yang memenuhi kriteria inklusi dan eksklusi sebanyak 30 orang. Kriteria inklusi yaitu pasien remaja, dewasa, dan lansia, pasien CAP yang menggunakan terapi tunggal seftriakson I gram selama 5 hari, pasien BPJS Kesehatan rawat inap kelas 2 dan 3, dan pasien dengan catatan keuangan lengkap. Kriteria eksklusi adalah pasien keluar rumah sakit dengan status pulang paksa dan meninggal dunia, pasien yang menjalani operasi, dan pasien ibu hamil.

Instrumen yang digunakan adalah lembar pengumpul data. Komponen biaya yang dihitung adalah biaya langsung medis (biaya obat, IGD, dokter, perawatan, akomodasi, dan laboratorium). Masingmasing komponen biaya tersebut dijumlahkan pada setiap pasien dan masing-masing kelas rawatan. Hasil yang didapatkan kemudian dijumlahkan menjadi total biaya langsung medis, rata-rata biaya langsung medis perpasien, rata-rata komponen biaya, dan rata-rata biaya langsung medis per kelas rawatan.

\section{HASIL DAN PEMBAHASAN}

Hasil penelitian ini didapatkan data univariat berupa karakteristik responden dan biaya langsung medis pasien pneumonia di RSUD X di NTB tahun 2018 berdasarkan perpektif BPJS Kesehatan.

Tabel I. Karakteristik Pasien Pneumonia

\begin{tabular}{|l|c|c|}
\hline Karakteristik & $\begin{array}{c}\text { Jumlah } \\
(\mathrm{N})\end{array}$ & $\begin{array}{c}\text { Persentase } \\
(\%)\end{array}$ \\
\hline Jenis Kelamin & & \\
I. Laki-laki & I7 & 56,67 \\
2. Perempuan & I3 & 43,33 \\
\hline Umur & & \\
I. $\leq 45$ tahun & I4 & 46,67 \\
2. $>45$ tahun & I6 & 53,33 \\
\hline Total & 30 & I00 \\
\hline
\end{tabular}


Berdasarkan tabel I tersebut, sesuai dengan penelitian Nuraini (2012), yang menyatakan bahwa pasien penumonia lebih banyak terjadi pada laki-laki (69,23\%) dibandingkan pada perempuan (30,77\%). Pneumona berdasarkan umur juga sesuai dengan penelitian Wulandari (2016) menunjukkan bahwa kejadian pneumonia paling banyak pada usia 56-65 tahun $(38,89 \%)$ dan pneumonia semakin sering dijumpai pada lansia (Dahlan, 2007).

Tabel 2 Biaya Langsung Medis Pasien Pneumonia

\begin{tabular}{|c|c|c|}
\hline en Biaya & $\begin{array}{l}\text { Total Biaya } \\
\text { (Rp.) }\end{array}$ & $\begin{array}{l}\text { Rata-rata } \\
\text { Biaya } \\
\text { (Rp.) }\end{array}$ \\
\hline Biaya Obat $\mathrm{Se}$ & 2.948 .089 & 195.019 \\
\hline Kelas & I.754.572 & I03.210 \\
\hline Kelas 3 & I.193.5I7 & 91.809 \\
\hline Biaya Obat & I9.040.992 & I. 286.420 \\
\hline Seftriakson & 9.849 .495 & 579.382 \\
\hline $\begin{array}{l}\text { Kelas } 2 \\
\text { Kelas } 3\end{array}$ & 9.191.497 & 707.038 \\
\hline Biaya & I2.340.000 & 805.158 \\
\hline & 7.96 & 468.235 \\
\hline Kela & 4.380 .000 & 336.923 \\
\hline Biay & I8.300.000 & I.I87.783 \\
\hline & I2.Is & 714.706 \\
\hline Kela & 6.150 .000 & 473.077 \\
\hline Biaya Perawatan & I4.66I.800 & 977.246 \\
\hline & 8.319 .800 & 489.400 \\
\hline Kelas 3 & 6.342 .000 & 487.846 \\
\hline Biaya Labora & 7.127 .400 & $45 \mathrm{I} .657$ \\
\hline & 5.337 .400 & 313.965 \\
\hline Kel & 1.79 & I37.692 \\
\hline Biaya IC & I6.630.668 & I.I I I.947 \\
\hline & 9.245 .2 & 543.839 \\
\hline Kelas 3 & 7.385 .408 & 568.108 \\
\hline
\end{tabular}

Dari Tabel II tersebut, biaya total dan rata-rata biaya langsung medis tertinggi pada biaya obat selain sefriakson, biaya akomodasi, dan biaya IGD. Biaya obat selain seftriakson terdiri dari obat inhaler UDV, warfarin, ambroksol, omeprazole, dll.

Tabel 3. Rata-rata Biaya Langsung Medis Perkelas

\begin{tabular}{|l|c|c|}
\hline Kelas Perawatan & $\begin{array}{l}\text { Total Biaya } \\
\text { (Rp.) }\end{array}$ & $\begin{array}{l}\text { Rata-rata } \\
\text { Biaya (Rp.) }\end{array}$ \\
\hline Kelas 2 & 54.616 .527 & 3.212 .737 \\
\hline Kelas 3 Biaya & 36.432 .422 & 2.802 .494 \\
\hline $\begin{array}{l}\text { Total Rp. 9I.048.949 } \\
\text { Langsung Medis }\end{array}$ & \multicolumn{2}{|c|}{ Rp. 3.034.965 } \\
\hline $\begin{array}{l}\text { Rata-rata Biaya } \\
\begin{array}{l}\text { Langsung Medis } \\
\text { (perpasien) }\end{array}\end{array}$ & \\
\hline
\end{tabular}

Hasil penelitian ini menunjukan bahwa rata-rata biaya langsung medis tertinggi pada kelas 2 yaitu sejumlah $\mathrm{Rp}$. 3.2I2.737,- dengan rata-rata biaya langsung medis secara keseluruhan sejumlah Rp.3.034.965,- per pasien. Hasil ini sesuai dengan penelitian Nuraini dkk (20I2) yaitu biaya paling tinggi pada pasien rawat inap kelas 2 (Rp.I.780.490) dibandingkan dengan kelas 3 (Rp.I.582.530).

\section{SIMPULAN}

Rata-rata biaya langsung medis penggunaan obat seftriakson pada pasien pneumonia sebesar Rp.3.034.965,- per pasien. Rata-rata biaya langsung medis penggunaan obat seftriakson pada pasien kelas 2 sebesar Rp.3.2I2.737,- per pasien, sedangkan ratarata biaya langsung medis penggunaan obat seftriakson pada pasien kelas 3 sebesar Rp.2.802.494,-.

\section{REFERENSI}

Abegunde, D. 20I0, Inefficiencies due to Poor Access to and Irrational Use of Medicines to Treat Acute Respiratory Tract Infections in Children, World Health Organization (WHO), Geneva.

Bootman, J. L., Townsend, R. J., and McGhan, W. F., 2005, Principles of Pharmacoeconomics, 3rd Ed., I-I8, Harvey Whitney Book Company,USA.

Bauer, T.T., Welte, T., Ernen, C., Schlosser, B.M., Waschke, I.T., Zecuw, J., Werninghaus, G.S., 2005, Cost Analysis of Community Acquired Pneumonia From the Hospital Perspective, Chest, 2005, I28. 22382246.

Dahlan, Z., 200I, Buku Ajar Ilmu Penyakit Dalam Jilid II Edisi IV, Pusat Penerbitan Departemen Ilmu Penyakit Dalam FKUI, Jakarta.

Dahlan, Z., 2007, Buku Ajar Ilmu Penyakit Dalam Jilid II Edisi IV, Pusat Penerbitan Departemen Ilmu Penyakit Dalam FKUI, Jakarta.

Depkes RI., 2005, Pharmaceutical Care Untuk Infeksi Saluran Pernafasan, Departemen Kesehatan Republik Indonesia, Jakarta.

Glover, M.L., Reed, M.D., 2005, Lower Respiratory Tract Infections Chapter 106, dalam Dipiro, J.T., Talbert, R.L., Yee G., Matzke, G.R., Wells, B.G., and Pryes, L.M., Pharmacotherapy A Pathophysiologic Approach Sixth Edition, I956-I958, The Mc-Graw Hill Companies, Inc, USA.

Kemenkes RI, 20I3. Pedoman Penerapan Kajian Farmakoekonomi. Jakarta. 
Nuraini, 20I2, Gambaran Pengobatan dan Analisi Biaya Terapi Pneumonia Pada Pasien Anak di Instalasi Rawat Inap RS "X" Tahun 20II, Naskah publikasi, Fakultas Farmasi Universitas Muhammadiyah Surakarta, Surakarta.

Nursyafrisda, 20I0. Analisis Efektifitas Biaya Penggunaan Ceftriaxone dan Cefotaxime Pada Pasien Pneumonia Balita di Rawat Inap RSU Kab. Tanggerang. Tesis Fakultas Kesehatan Masyarakat: Depok

Purwaningrum, R., 2007, Kajian Kerasionalan dan Biaya Penggunaan Antibiotika pada Terapi Pneumonia di Rumah Sakit PKU Muhammadiyah Yogyakarta, Skripsi, Fakultas Farmasi, Universitas Ahmad Dahlan, Yogyakarta.

Puteri, Teti Dynaila. 2012. Analisis Biaya Penggunaan Antibiotik Pada Pasien Pneumonia Di Instalasi Rawat Inap IRNA Anak RSUP Dr. M. Djamil Padang. Naskah Publikasi. Program Pascasarjana Universitas Andalas: Padang.

S. Wardhani TB. 20II. Analisis Efektivitas Biaya Penggunaan Antibiotik Pada Pasien Pneumonia Komunitas Rawat Inap Di RSUD Kabupaten Cilacap Tahun 200820I0. Naskah Publikasi Farmasi FMIPA Universitas Islam Indonesia: Yogyakarta.

Vogenberg, F. R., 200I, Introduction to Applied Pharmacoeconomics, McGraw-Hill Companies, USA.

Wulandari D.N. 20I6. Efektivitas Penggunaan Antibiotik Ceftriaxone Pada Pasien Pneumonia Dewasa Di Instalasi Rawat Inap RSUD Dr. Moewardi Surakarta Tahun 20I4-20I5. Naskah Publikasi Universitas Sebelas Maret: Semarang. 